University of Nebraska - Lincoln

DigitalCommons@University of Nebraska - Lincoln

Faculty Publications of the Center on Children, Families, and the Law

Children, Families, and the Law, Center on

2021

\title{
"Born Under My Heart": Adoptive Parents' Use of Metaphors to Make Sense of Their Past, Present, and Future
}

Lucas Hackenburg

Toni Morgan

Eve Brank

Follow this and additional works at: https://digitalcommons.unl.edu/ccflfacpub

Part of the Administrative Law Commons, Courts Commons, Criminology and Criminal Justice Commons, Domestic and Intimate Partner Violence Commons, Family Law Commons, Family, Life Course, and Society Commons, Juvenile Law Commons, Law and Psychology Commons, Law Enforcement and Corrections Commons, Nonprofit Organizations Law Commons, Social Policy Commons, Social Welfare Commons, and the Social Welfare Law Commons

This Article is brought to you for free and open access by the Children, Families, and the Law, Center on at DigitalCommons@University of Nebraska - Lincoln. It has been accepted for inclusion in Faculty Publications of the Center on Children, Families, and the Law by an authorized administrator of DigitalCommons@University of Nebraska - Lincoln. 


\title{
"Born Under My Heart": Adoptive Parents' Use of Metaphors to Make Sense of Their Past, Present, and Future
}

\author{
Lucas Hackenburg, ${ }^{1}$ Toni Morgan, ${ }^{2}$ and Eve Brank ${ }^{1}$ \\ 1 Center on Children, Families, and the Law, University of Nebraska- \\ Lincoln, Lincoln, NE, USA \\ 2 St. Norbert College, De Pere, WI \\ Corresponding author - Eve Brank, Center on Children, Families, and the Law, \\ University of Nebraska-Lincoln, 206 S. 13th Street, Suite 1000, Lincoln, NE \\ 68588-0227, USA; email ebrank2@unl.edu \\ ORCID - Lucas Hackenburg https://orcid.org/0000-0002-2021-7309
}

\begin{abstract}
Metaphors provide the opportunity to make sense of our experiences and share them with others. The current research qualitatively examined interviews with adoptive parents who had adopted through intercountry or private adoptions. Throughout their interviews, each participant used at least one metaphor in describing their experiences of adopting and raising their child. Overarchingly, the metaphor of "Adoption is a journey" encapsulated parents' experiences. To demonstrate the journey, parents used metaphors to describe the past, present, and future. Metaphors of the past focused on their child's trauma and the origin of how the child came to join their family. Metaphors used to describe the present were challenge metaphors, including child's behaviors and finding support, coping metaphors, and balance metaphors. Lastly, metaphors of the future included guiding and commitment metaphors. In addition to metaphors, parents used symbolic rituals to connect their children with their past and current family. From metaphors, we offer several
\end{abstract}

Published in The Family Journal: Counseling and Therapy for Couples and Families (2021), 8pp. DOI: $10.1177 / 10664807211027310$

Copyright (c) 2021 Lucas Hackenburg, Toni Morgan, and Eve Brank. Published by SAGE Publications. Used by permission. 
practical implications for postadoption intervention. First, interventions should be developed to meet participants where they are. Second, interventions should focus on the overall picture of adoption, as parents make sense of their past experiences and their ideals about the future. Lastly, services should focus on tools, not fixes.

Keywords: adoption, family communication, metaphors, parent-child relationships, private adoption, international adoption

\section{Introduction}

More than 100,000 children are adopted in the United States through either intercountry adoption or private domestic adoption (Child Welfare Information Center, 2016; Selman, 2018). Adoptive families must engage in discursive practices to develop their family identity (Galvin, 2006; Suter, 2014). Families with adoptive children compared to families with only biological children tend to experience higher levels of stress (Harris-Waller et al., 2016) and identity disruptions (Mariscal et al., 2015), but also seek out support more often (Leung et al., 2005). Through metaphors and communicative sense-making, the current study analyzed interviews from 40 adoptive parents who completed adoption through private domestic adoption or intercountry adoption and completed a postadoption intervention as part of the National Quality Improvement Center for Adoption and Guardianship Support and Preservation (QIC-AG), which was funded by the Department of Health and Human Services, Administration for Children and Families, Children's Bureau.

\section{Background}

All children who have been fostered or adopted have likely experienced some form of trauma (American Academy of Pediatrics, 2016). The trauma experienced by adoptive children presents challenges to adoptive parents and family systems (McDonald et al., 2001). Being adopted can be considered trauma itself due to feelings of uncertainty and identity issues (Dance \& Rushton, 2005; Mariscal et al., 2015). Adopted children may manifest this trauma in psychological and behavioral issues (Cassidy \& Mohr, 2001; Duncan \& Miller, 2002; Hanna et al., 2011; Pollak 2008), which increases parental stress (Harris-Waller et al., 2016). 
The QIC-AG worked with eight sites across the nation, with the purpose to implement evidence-based interventions or develop and test promising practices which, if proven effective, could be replicated or adapted in other child welfare jurisdictions (see, QIC-AG Permanency Continuum Framework, n.d.). The project's short-term outcomes varied by site and included, for example, increased level of caregiver commitment, reduced levels of family stress, improved familial relationships, and reduced child behavioral issues. The project had three long-term outcomes: increased postpermanency stability, improved behavioral health for children, and improved child and family wellbeing. The QIC-AG was primarily focused on adoptions through the public child welfare system, but the current research focused only on four sites and the subpopulation families that adopted through private domestic or intercountry processes

Communicatively Making the Adoptive Family. Humans often make sense of difficulties, relationships, and challenges, through interacting with other people. Suter (2014) expands on Galvin's (2006) internal and external boundary typologies of adoptive families and calls for work on how adoptive families make sense of their experiences and accomplish identity through narratives. Koenig Kellas and Kranstuber Horstman (2015) label this process CSM. Koenig Kellas and Kranstuber Horstman's (2015) articulation of CSM includes a number of sense-making approaches that people use, including memorable messages (e.g., Knapp et al., 1981), accounts (e.g., Scott \& Lyman, 1968), attributions (e.g., Manusov, 2018), storytelling (e.g., Koenig Kellas, 2005), and communicated perspectivetaking (e.g., Koenig Kellas et al., 2013).

Metaphors. In more recent work, other CSM scholars have argued that metaphors also function as a CSM device (Flood-Grady et al., 2020; Horstman et al., 2020). At their core, metaphors allow "us to comprehend one aspect of a concept in terms of another" (Lakoff \& Johnson, 1980, p. 10). Lakoff and Johnson argue that metaphors are particularly useful when defining abstract concepts, because, unlike a dictionary definition that focuses on the inherent properties of a concept, metaphors allow us to understand concepts as people in everyday life experience them. 
As articulated in previous sections, adoptive parents may struggle to make sense of the challenge of adoption as well as finding ways to articulate the everyday difficulties of parenting a child who has experienced trauma. Investigating adoptive parents' use of metaphors to explain their adoption experience may yield insightful results into how they are making sense of these challenges. Several studies have examined how metaphors function in adoptive families. For example, Suter et al. (2011a) conducted an analysis of how transracial international adoptive parents made sense of others' remarks about their family using metaphors. They identified the primary metaphor of the "adoptive family as battleground" (p. 45), suggesting that these remarks promoted a "traditional view [that was]... both reinforced and constituted by racist, biologically normative, and nationalist beliefs, which, when instantiated in talk (e.g., racist remarks), represents assaults on transracial, international adoptive families" (p. 47). In an additional analysis, parents' metaphor use suggested that they viewed themselves as their children's "protector" and "educator" (Suter et al., 2011b, p. 242). Frequently, parents struggling with infertility and who pursue adoption use the metaphor of pregnancy to make sense of their experience. For example, many mothers speak about preparing for the adoption of a child in the same terms that they would use for their own pregnancy, such as "It's the same thing really, just that you got on a plane and travelled for 20 hours instead of 20 hours of labor, you know?" (Lockerbie, 2014, p. 466).

Each of these examples illustrates how utilizing a lens of metaphor in analysis provides scholars with an in-depth understanding of how humans are making sense of their lives. Adoptive parents learning about their child's trauma as well as sometimes unlearning and relearning how to parent a child who has experienced significant trauma is an understandably challenging task. Some adoptive parents may struggle to put into words what this experience is like; careful attention to metaphorical language describing these challenges may yield important insights into how adoptive parents are processing the adoption experience and the adoption interventions in which they participated. Therefore, we ask the following research question: How do metaphors help adoptive parents who have participated in an adoption permanency intervention make sense of their experiences as an adoptive family? 


\section{Method}

To answer this question, we analyzed semistructured interviews with 40 private and intercountry adoptive parents taken from four QICAG adoption intervention sites. All four interventions examined in the current study focused on families who had already finalized their adoptions. Two interventions were selective services that were designed for families at risk for discontinuity and focused on prevention of problems. The first selective services, the Trauma Affect Regulation: Guide for Education and Therapy (implemented in Illinois) is an in-home intervention that is designed to enable youth affected by trauma and adverse childhood experiences to recognize, understand, and gain control of their stress reactions (Ford \& Hawke, 2012). The second selective services, Tuning in to Teens (implemented in New Jersey) focused on helping parents better understand their child's emotions, so their responses are appropriate and help the child develop and improve their emotional well-being (Kehoe, 2014). The third intervention was an indicated service meaning it focused on interventions that seek to address a specific need a family requested assistance to address. This intervention, Adoption and Guardianship Enhanced Support (implemented in Wisconsin and developed specifically for the QIC-AG) enhanced case management services by offering families individualized assessment of their strengths and needs, identification of child- and family-specific goals, personalized assistance with identifying resources and navigating services, and targeted advocacy. The fourth intervention was an intensive service, which means the focus was on providing immediate services and support for families in crisis or near crisis. The Neurosequential Model of Therapeutics (NMT) assessment (implemented in Tennessee) helps clinicians organize a child's developmental history and current functioning to inform the clinical decision making and treatment planning process (Perry, 2006). NMT guides the selection of the most appropriate, developmentally sensitive interventions for a child.

While each individual intervention had specific intended outcomes, all four shared several common desired outcomes, including increasing postpermanency stability, the behavioral health of the adopted child, and family well-being, parent's understanding of the child's behavioral health, permanency commitment, and caregiver commitment. 
Therefore, these data represent a wide variety of adoptive experiences while also sharing several common goals.

At the same time, these data are not a representative sample of all adoptive parents in the United States. The families in the present study all adopted children through private domestic or intercountry adoptions. Additionally, participants had all completed their respective intervention and self-selected into the current study.

\section{Participants}

Forty private and intercountry adoptive mothers $(n=33)$ and fathers $(n=7)$ participated in the study. Thirty-nine parents identified as White/Caucasian and one parent identified as Black/African American. One parent was between the ages of 25 and 34 years, seven parents were between the ages of 35 and 44 years, 19 parents were between the ages of 45 and 54 years, and 13 parents were between the ages of 55 and 64 years. Most parents were married $(n=36)$, three were divorced and one was single/never married.

Twenty-one participants adopted their child through a private domestic adoption and 19 participants adopted their child through an intercountry adoption. Sixteen parents adopted their child at birth or before the child was 1 year, six parents adopted their child when the child was 1 year old, eight parents adopted their child when the child was 2 years old, nine parents adopted their child sometime between the ages of 3 and 14 years, and one parent did not report how old their child was at the time of the adoption. Eighteen parents identified their child's racial identity as White/Caucasian, five parents identified their child's racial identity as Black/African American, five parents identified their child's racial identity as Hispanic/Latino, seven parents identified their child's racial identity as Asian/Pacific Islander, and five parents identified their child's racial identity as multi or biracial. Finally, adopted children that the participants reported on included 25 males and 15 females.

\section{Procedures}

After obtaining approval from our own Institutional Review Board as well as all intervention sites, on-site employees in each of the four 
interventions provided potential participants with information regarding the current study. Interested parents completed consent forms and an initial scheduling survey to indicate availability for their participation. On-site employees sent this information to our research team and we then contacted all interested participants to set up a telephone interview with each parent.

We used semistructured interviews in order to elicit parents' complex feelings and perceptions of their adoption experience as well as their experience completing the intervention. Semistructured interviews provide a space for participants to voice these experiences and allow for a depth of sense making that other data collection methods cannot (Charmaz, 2006). During the semistructured interview, a member of the research team spoke with each parent about a number of different topics. The interview protocol included questions related to the specific interventions that the family completed as well as more general family functioning questions. Questions were related to self-efficacy and behavior intention (Lwin \& Saw, 2007), child's behavior (Stiffman, 1984), child's developmental needs (Bethell et al., 2002), child's personality (Dozier \& Lindhiem, 2006), the adopted child's identity (Colaner \& Soliz, 2017; Horstman et al., 2016), care-

giver's strain (Brannan et al., 1997), and parent's feelings about the adoption (Testa et al., 2015). All questions were adapted specifically to help the research team better understand the parent's experience with the adoption and outcomes from the individual interventions. At the end of the interview, participants were thanked for their time. If they consented to provide and share their physical mailing address, they were mailed a \$25 gift card as compensation for their time.

\section{Data Analysis}

Each semistructured interview was transcribed by a member of the research team, resulting in 611 single-spaced pages of data. All transcripts were then imported to Dedoose for in-depth coding. While parents were not explicitly prompted to think about or talk about their adoption experience through metaphors and non-literal language, all parents did at some point during their interview.

Transcripts were analyzed using the constant comparison method (Strauss \& Corbin, 1998). First, researchers read through all of the 
transcripts and independently coded for figurative language and metaphors. Axial coding was then used to group similar codes into categories. Lastly, the categories were grouped into themes. The themes were then organized to establish coherence. To establish validity, rich, thick descriptions are provided to connect themes (Creswell \& Poth, 2018; Tracy, 2013).

\section{Results}

\section{“Adoption as a Journey"}

The overarching metaphor from participants' responses was, "Adoption is a journey." Several participants explicitly stated this in their responses. One parent said, "Adoption is a journey. You have to remember the whole part" (44; participant numbers are noted in parentheses following excerpts). Others drew on the past to describe their current experiences and their goals of looking towards the future. During each of these timeframes (past, present, and future), parents used metaphors to help them make sense of their experiences.

Metaphors to Make Sense of the Past. In their journey, parents used metaphors to make sense of the past. Two categories of metaphors emerged: trauma metaphors and origin metaphors. These metaphors were used to help parents and their children make sense of the circumstances that brought them together as a family.

Trauma metaphors. Parents used metaphors as ways to understand and describe their child's history of trauma. One parent explicitly linked adoption to trauma, saying, "It was trauma. It is trauma. It took me a long time to accept that that's trauma for these kiddos to go through, and you have to provide them with a safe place to be" (33). Another parent described it as, "It's almost like a wound from the beginning from being separated from their birth mother... it's heartbreaking that they think you'll just leave them there. I mean, that's how strong this primal wound is" (6). Similarly, one parent said, "He probably thinks of himself this way but like as a victim" (43). Another parent used a metaphor to describe how their child's previous experiences affected their ability to connect with their child, saying, "But 
I feel like there's a crack in the pot. I feel like you pour and pour and pour in and it leaks out... We even try putting a little extra sometimes in his pot, and it just leaks out. So there are just things that we cannot make up for... it just seems like that missing stuff from that early part is not as easy to replace as we expected it would be" (26) and "It's like a child drowning, and I can't help her. She's in such a low place. How could you get there?" (31). Another said, "She's a fighter" (1). Through these metaphors, parents were able to make sense of their child's past and become more empathetic to their experiences.

Origin metaphors. Origin metaphors were used to describe how their adopted children first came into the family. One parent said, "It was Plan A. This was not Plan B. This was Plan A for our family, and they [adopted child] were always meant to be our daughter" (31). Another parent reported, "Getting them was my blessing from God. That was my gift" (23). One parent used a metaphor to remove the distinction between biological and adoption, saying, “'They were born under my heart,' I say. I have not given birth to them, but yet, in my heart, I have" (6). One parent said that completing the intervention, “...really helped me have some breakthroughs of feeling more like a mother, and not just like a babysitter or someone waiting for her mother to come pick her up" (21). Metaphors about the child's origins were used by parents to help their children understand why they were in the family.

Metaphors to Make Sense of the Present. Given that the participants were recruited from parents who were targeted for recruitment based on a set of characteristics that each site determined was a risk for postpermanence discontinuity, it is unsurprising that parents' sense of the present was focused on challenges and conflict management strategies learned through the intervention site. Metaphors that emerged about the present included challenge metaphors, coping metaphors, and balance metaphors.

Challenge metaphors. Parents frequently used metaphors to describe challenges to raising their children and how reactive their child was. Challenge metaphors included metaphors about their child's challenging behaviors and difficulty finding support. Frequently used metaphors to describe their child's behaviors included, "flying off the handle... it's just an uphill battle" (35), "Sometimes we walk on eggshells around her to keep the peace" (44), and "I wouldn't try to have 
a conversation with him when he's in full war mode" (36). Another parent said, "It was like we adopted a little monster, literally" (8). To describe their child's developmental delay, one parent said, "I like to call it Life 101 that he struggles. We can't leave him home alone, just because he has no perception of what's going on around him" (36). One parent described the end of the school year as, "we are in survival mode" (52). These metaphors helped parents make sense of the emotional and developmental challenges their child faces and understand the needs of their child.

In addition to describe the child's behaviors, parents used metaphors to describe how difficult it was to find support. One parent said, "You're constantly running in circles, trying to figure out where to go and how to handle things" (32). Another said, "You feel like you're butting your head into a wall, and the wall never moves" (23). Another parent stated, "We were pretty much in a kind of self-destruct mode before the therapy" (24). One parent described the numerous counselors they attempted to get for their daughter, but discontinued numerous times, saying, "Again, we jumped ship" (31). These parents described that when their children were difficult, they felt additional stress of not only finding support, but support that was effective.

Coping metaphors. Parents frequently used metaphors to describe what they learned in their interventions to help them manage conflict with their child. One parent described their experience as, "It felt like he used to be drowning, if he's in the water, I'm flailing with him versus trying to toss him a lifesaver" (43). Expressing similar sentiments, another parent said, "You're always groping and grasping as it appears to be in the dark. Now, I've got a light switch turned on over there, so there's something rather than me just being left by myself" (36).

Another parent talked about how interventions helped them develop ways to develop an understanding with their child through metaphorical zones (6), including helping their children voice when they were "off limits" until they get to a spot they need to be (31) and alarm systems in the brain that may be triggering specific reactions (33). These coping strategies helped parents feel like they could manage the conflict with their children.

Several parents used the metaphor of their family as a team to connect with their child. One parent stated, "We talk about being a team, and we're there for one another. When one of us does well, 
it's good for all of us" (2). Another said, "We're on your team. I'm on your team" (43) and "I think that helped him see that," "Hey, we're all here because it's a team effort" (47). Parents were able to reframe their children's feelings through connection rather than competition.

Balance metaphors. Parents used balance metaphors to cope with the challenges and maintain hope for the future. The primary idea behind the balance metaphors was that they will always have both progress and setbacks. One parent said, "We feel like we're three steps forward when something really great happens, and then we'll go slide back two steps" (44). Another said, "We've been in kind of a tough season with school difficulties" (43). Another stated, "You know he's a little bit of a Jekyll and Hyde. He's either super, super sweet or he's just very, very difficult...he's literally my greatest challenge and greatest joy" (8). Another said, "I know once all that [frustration] gets out, the rainbow comes later" (6). These metaphors emphasized that both the good and bad were temporary, helping them prepare for the challenges and appreciating the rewards.

An important function of the balance metaphors was that it helped parents understand that the coping mechanisms they learned were tools, not simple fixes. One said, "I don't think me completing the program changed him like a light switch" (9). Another said, "It definitely made me realize what that phrase, 'It's not a sprint; it's a marathon' means" (47). In sum, "it's just kind of a rollercoaster (41)... and you just have to kind of ride it out" (47). Balance metaphors were parents' way of recognizing that there are going to be good days and bad days. These metaphors helped parents cope with the fact that the challenges were not permanent nor necessarily fixable.

Metaphors to Make Sense of the Future. Parents used metaphors to describe their visions for the future. These metaphors were guiding metaphors and commitment metaphors.

Guiding metaphors. Parents used guiding metaphors to express their desire to act as long-term supports for their children. One parent said, "I think we all want a stable foundation as we grow up, so that as we get into adulthood, we have something to cling to and give him that good home base" (47). Another stated, "I pray that I am a buoy or the lighthouse that he can always come back to" (43). Looking towards their future, one parent said, "I wish I could go ahead 
in the future and see what she's going to be like when she's twentyfive and thirty and forty years old... I'm determined to make her, you know, turn her into a good person” (35). Another said, “I'm kind of hoping that through the long haul, he will see that it's positive when gets passed some of those stumbling blocks on the pathway" (28). These parents used these metaphors to acknowledge the challenges they currently face with their children, but also the belief that they can be a positive support for their children moving forward.

Commitment metaphors. The final category was commitment to keeping the child. These metaphors were used inside and outside the family to assure they would never give the child up. Parents used metaphors to reinforce their commitment to raising their adopted child. One parent said, "I didn't adopt with the intention of a trial period. I mean, I adopted forever" (23). Another said, "I always said our family did not feel complete until he came into the picture, so there would be a hole [if he wasn't here]" (43). Similarly, another parent said, "Our lives would feel very empty because all of the issues with him kind of fills up the available space" (24). Another simply said, "I mean, we're in it for the long haul" (12). For them, the children were part of their "forever family" (6).

\section{Rituals}

In addition to using metaphors and verbal discourse to manage their relationships with their children, parents reported engaging in symbolic celebrations with their adopted children. Many parents reported “celebrating adoption days like birthdays" (23), or "got ya days" (31). Another parent described a celebration of sending a balloon into the air as a way for their child to connect to their birth parents, saying “'Let's send a balloon up for your birth mother'. I just felt it would make them think about it more and with China there's no way they can track that. There's no way they can go back and try to find their birth mother or birth father" (31). Other parents who had knowledge of their child's birth family described crafting scrapbooks of their birth family with them (29) and another talked about having their children write letters and decide pictures they would show their birth parents if they were to meet them (33). These symbolic celebrations helped manage the children's identities by symbolically connecting them to their birth families and celebrating their adoption. 


\section{Discussion}

The QIC-AG sought to implement evidence-based interventions or develop and evaluate promising interventions that increase long-term stability and permanency for adoptive families. Framed through discourse-dependent families (Galvin, 2006) and communicative sensemaking (Koenig Kellas \& Kranstuber Horstman, 2015), the current exploration of private and intercountry adoptive parents' use of metaphors and symbolic celebrations examined how they make sense of their experiences as adoptive parents after completing one of four QIC-AG interventions. The primary metaphor parents used to describe their adoption experience was "adoption as a journey," focused on making sense of the past, present, and future. The second form of discourse was symbolic celebrations that helped their children connect with their identities as adopted children. By focusing on how adoptive parents explain and process their experience, we depart from the overall examination of long-term stability and permanency. Such a focus provides a personal narrative and begins to fill in the lived experiences for these families.

A growing body of research suggests that developing a positive identity is important for adopted children, yet previous literature suggest that identity development is nuanced. In the examination of entrance narratives, Kranstuber and Koenig Kellas (2011) found that narratives that contained positive themes of becoming part of the family reported higher selfesteem than adopted children whose stories focused on themes of negative connections to their birth family. Parents play an important role in framing these narratives (Suter, 2008; Suter et al., 2011b). Like the idea of entrance narratives, origin metaphors in the current study presented similar themes, largely centered on gifts and fate. Additionally, it is important that adoptive parents are informed on trauma-based care, given the high prevalence of trauma related to adoption (Mariscal et al., 2015; Miller et al., 2018). Metaphors provide the opportunity to talk about uncomfortable topics such as trauma and make them more approachable.

The current study's specific concentration on metaphors allowed us to examine adoption as an integrative process, focused on changing family dynamics. Adoption can be a long, difficult process for many people (Coakley \& Berrick, 2008; Smith et al., 2006). It is important 
for parents to recognize these experiences and validate the child's trauma involved in the process (Dance \& Rushton, 2005; Mariscal et al., 2015; Miller et al., 2018). Additionally, adoptive parents must be prepared to commit to the adoption (Mariscal et al., 2015).

\section{Implications}

Several implications can be derived from understanding how parents use metaphors to make sense of their experiences of adoption. First, previous literature outlined the need for adoptive parents to understand trauma-based training. Not only is access to such interventions important, but they must be effective. The metaphors used by participants in this study demonstrate how parents understand trauma and can be used to develop training interventions to make them more accessible and usable to parents. These interventions should meet parents where they are to begin addressing trauma in terms they understand.

Second, training interventions could be implemented to engage parents in their children in being mindful of how they frame their adoption experience and engaging in activities with the children to connect with their past. The frequently used metaphor of adoption as a journey focuses on adoption as a lasting process that has a history and implications for the future. Interventions should focus on the "big picture" of the adoption and that relationships will develop and change over time. Interventions should be prepared to help manage evolving family identities. This may be particularly important in considering family relationships with the birth families and helping children adjust. Parents can engage with their child about their history to help them understand their history.

Lastly, interventions should emphasize that the skills being taught are meant to be utilized as tools to manage day-to-day stress and conflict, not "fix." The balance metaphors reinforce that there are good and bad days.

\section{Limitations}

The findings and implications of this study should be taken in light of several limitations. First, participants were recruited from different study sites. It is not possible to draw larger conclusions related to 
each intervention. Experimental designs could be implemented to develop specific outcomes of each intervention. Second, the parents in this study completed interviews after completing postadoption services. Future studies should consider how families who have not utilized postadoption services use metaphors to understand their experiences. Third, all except one of the parents in this study were White. Future research should consider how adoptive parents' and children's race influence how adoptive parents make sense of their adoption experiences. Lastly, this study only examined the metaphors used by adoptive parents. Future research should consider how adoptive children use metaphors to make sense of their experiences.

\section{Conclusion}

Adoptive families rely on communication and interaction to make sense of their experiences (Galvin, 2006; Koenig Kellas \& Kranstuber Horstman, 2015). Forty adoptive parents described their adoption experiences using metaphors to make sense of their past, present, and future. These metaphors helped them understand, connect, and make sense of their relationship with their children. The results of this study argue for a more integrative look at the adoption experience. Future interventions should focus on how the use of metaphors can be used to help parents make sense of their experiences to promote stability and well-being of adoptive families.

Acknowledgments The authors thank Leslie Cohen for her input and assistance with the project.

Conflicting Interests The authors declared no potential conflicts of interest with respect to the research, authorship, and/or publication of this article.

Funding The authors disclosed receipt of the following financial support for the research, authorship, and/or publication of this article: The current research was funded through the Department of Health and Human Services, Administration for Children and Families, Children's Bureau, Grant 9oCO1122. The contents of this report do not necessarily reflect the views or policies of the funders, nor does mention 
of trade names, commercial products or organizations imply endorsement by the U.S. Department of Health and Human Services. This information is in the public domain. The Intercountry and private adoption focus of the National Quality Improvement Center for Adoption and Guardianship Support and Preservation was funded through a cooperative agreement between the Children's Bureau, Spaulding for Children, and the University of Nebraska-Lincoln.

\section{References}

American Academy of Pediatrics. (2016). Helping foster and adoptive families cope with trauma. [PDF File]. Retrieved from https://www.aap.org/en-us/ Documents/hfca_foster_trauma_guide.pdf

Bethell, C. D., Read, D., Stein, R. E. K., Blumberg, S. J., Wells, N., \& Newacheck, P. W. (2002). Identifying children with special health care needs: Development and evaluation of a short screening instrument. Ambulatory Pediatrics, 2(1), 38-48. https://doi.org/10.1367/1539-4409(2002)002<0038:ICWSHC >2.0 .CO;2

Brannan, A. M., Heflinger, C. A., \& Bickman, L. (1997). The caregiver strain questionnaire: Measuring the impact on the family of living with a child with serious emotional disturbance. Journal of Emotional and Behavioral Disorders, 5(4), 212-222. http://doi.org/10.1177/106342669700500404

Cassidy, J., \& Mohr, J. J. (2001). Unsolvable fear, trauma, and psychopathology: Theory, research, and clinical considerations related to disorganized attachment across the lifespan. Clinical Psychology: Science and Practice, 8(3), 275-298. http://doi.org/10.1093/clipsy.8.3.275

Charmaz, K. (2006). Constructing grounded theory: A practical guide through qualitative analysis. SAGE.

Child Welfare Information Gateway (2016). Trends in U.S. adoptions: 2008-12. U.S. Department of Health and Human Services, Children's Bureau.

Coakley, J. F., \& Berrick, J. D. (2008). Research review: In a rush to permanency: Preventing adoption disruption. Child \& Family Social Work, 13(1), 101-112. http://doi.org/10.1111/j.1365-2206.2006.00468.x

Colaner, C. W., \& Soliz, J. (2017). A communication-based approach to adoptive identity: Theoretical and empirical support. Communication Research, 44(5), 611-637. http://doi.org/10.1177/0093650215577860

Creswell, J. W., \& Poth, C. N. (2018). Qualitative inquiry and research design: Choosing among five approaches (4th ed.). SAGE publications.

Dance, C., \& Rushton, A. (2005). Joining a new family: The views and experiences of young people placed with permanent families during middle childhood. Adoption and Fostering, 29(1), 18-28. http://doi.org/10.1177/03085759050290 $\underline{0104}$

Dozier, M., \& Lindhiem, O. (2006). This is my child: Differences among foster parents in commitment to their young children. Child Maltreatment, 11(4), 338-345. http://doi.org/10.1177/1077559506291263 
Duncan, A., \& Miller, C. (2002). The impact of an abusive family context on childhood animal cruelty and adult violence. Aggression and Violent Behavior, 7(4), 365-383. http://doi.org/1016/S1359-1789(01)00064-7

Flood-Grady, E., Koenig Kellas, J., \& Chernin, K. A. (2020). Communicated sensemaking: A theoretical compass for exploring family communication and sensemaking about mental health and illness. In L. R. Lippert, R. D. Hall, A. E. Miller-Ott, \& D. Cochece-Davis (Eds.), Communicating mental health: History, contexts, and perspectives (pp. 27-51). Lexington Books.

Ford, J., \& Hawke, J. (2012). Trauma affect regulation psychoeducation group and milieu intervention outcomes in juvenile detention facilities. Journal of Aggression, Maltreatment, \& Trauma, 21(4), 365-384. http://doi.org/10.1080/1 0926771.2012 .673538

Galvin, K. M. (2006). Diversity's impact on defining the family. In L. H. Turner, \& R. West (Eds.), The family communication sourcebook (pp. 3-19). SAGE.

Hanna, M., Tokarski, K., Matera, D., \& Fong, R. (2011). Happily ever after? The journey from foster care to adoption. Adoption Quarterly, 14(2), 107-131. http://doi.org/10.1080/10926755.2011.560789

Harris-Waller, J., Granger, C., \& Gurney-Smith, B. (2016). A comparison of parenting stress and children's internalizing, externalizing and attachment-related behaviour difficulties in UK adoptive and nonadoptive families. Adoption \& Fostering, 40(4), 340-351. http://doi. org/10.1177/0308575916667911

Horstman, H. K., Colaner, C. W., \& Rittenour, C. E. (2016). Contributing factors of adult adoptees' identity work and selfesteem: Family communication patterns and adoption-specific communication. Journal of Family Communication, 16(3), 263-276. http://doi.org/10.1080/15267431.2016.1181069

Horstman, H. K., Holman, A., \& McBride, M. C. (2020). Men's use of metaphors to make sense of their spouse's miscarriage: Expanding the communicated sensemaking model. Health Communication, 35(5), 538-547. http://doi.org/10.1080 $\not 10410236.2019 .1570430$

Kehoe, E. K. (2014). TUNING IN TO TEENS: Examining the efficacy of an emotionfocused parenting intervention in reducing preadolescents' internalizing difficulties (doctoral dissertation). Melbourne School of Psychological Sciences, The University of Melbourne, Australia.

Knapp, M., Stohl, C., \& Reardon, K. (1981). Memorable messages. Journal of Communication, 31(4), 27-41. http://doi.org/10.1111/j.1460-2466.1981. tboo448.x

Koenig Kellas, J. (2005). Family ties: Communicating identity through jointly told family stories. Communication Monographs, 72(4), 365-389. https://doi. org/10.1080/03637750500322453

Koenig Kellas, J., \& Kranstuber Horstman, H. (2015). Communicated narrative sense-making: Understanding family narratives, storytelling, and the construction of meaning through a communicate lens. In L. H. Turner, \& R. West (Eds.), The SAGE handbook of family communication (pp. 76-90). SAGE. 
Koenig Kellas, J., Willer, E. K., \& Trees, A. R. (2013). Communicated perspectivetaking during stories of marital stress: Spouses' perceptions of one another's perspective-taking behaviors. Southern Communication Journal, 78(4), 326351. https://doi.org/10.1080/1041794X.2013.815264

Kranstuber, K. A., \& Koenig Kellas, J. (2011). "Instead of growing under her heart, I grew in it": The relationship between adoption entrance narratives and adoptees' self-concept. Communication Quarterly, 59(2), 179-199. http://doi.or g:10.1080/01463373.2011.563440

Lakoff, G., \& Johnson, M. (1980). Metaphors we live by. University of Chicago Press.

Leung, P., Erich, S., \& Kanenberg, H. (2005). A comparison of family functioning in gay/lesbian, heterosexual and special needs adoptions. Children and Youth Services Review, 27(9), 1031-1044. http://doi.org/10.1016/j. childyouth.2004.12.030

Lockerbie, S. (2014). Infertility, adoption and metaphorical pregnancies. Anthropologica, 56(2), 463-471. http://www.jstor.org/stable/24467319

Lwin, M. O., \& Saw, S. (2007). Protecting children from Myopia: A PMT perspective for improving health marketing communications. Journal of Health Communication, 12(3), 251-268. http://doi.org/10.1080/10810730701266299

Manusov, V. (2018). Attribution theory: Who's at fault in families? In D. O. Braithwaite, E. A. Suter, \& K. Floyd (Eds.), Engaging theories in family communication: Multiple perspectives (pp. 51-61). Routledge.

Mariscal, E. S., Akin, A. B., Lieberman, A. A., \& Washington, D. (2015). Exploring the path from foster care to stable and lasting adoption: Perceptions of foster care alumni. Children and Youth Services Review, 55(1), 111-120. http://doi. org/10.1016/j.childyouth.2015.05.017

McDonald, T. P., Propp, J. R., \& Murphy, K. C. (2001). The postadoption experience: Child, parent, and family predictors of family adjustment to adoption. Child Welfare, 8o(1), 71-94. https://pubmed.ncbi.nlm.nih. gov/11197063/

Miller, J. J., Niu, C., \& Moody, S. (2018). Investigating the child trauma knowledge of adoptive parents: An exploratory study. Adoption Quarterly, 21(4), 229-246. http://doi.org/10.1080/10926755.2019.1579134

Perry, B. D. (2006). The neurosequential model of therapeutics: Applying principles of neuroscience to clinical work with traumatized and maltreated children. In N. Boyd Webb (Ed.), Working with traumatized youth in child welfare (pp. 27-52). Guilford Press.

Pollak, S. D. (2008).Mechanisms linking early experience and the emergence of emotions: Illustrations from the study of maltreated children. Current Directions in Psychological Science, 17(6), 370-375. http://doi. org/10.1111/j.1467-8721.2008.00608.x

QIC-AG Permanency Continuum Framework (n.d.). Introduction to the QIC-AG Permanency Continuum Framework. https://qic-ag.org/wp-content/ uploads/2016/05/SFC-QICAG-00-Introduction1.pdf 
Scott, M. B., \& Lyman, S. (1968). Accounts. American Sociological Review, 33(1), 46-62. http://doi.org/10.2307/2092239

Selman, P. (2018). Global statistics for intercountry adoption: Receiving states and states of origin 2004-2017. Retrieved from https://www.hcch.net/es/ publications-and-studies/details4/?pid $=5891 \& d t i d=32$

Smith, S. L., Howard, J. A., Garnier, P. C., \& Ryan, S. D. (2006). Where are we now? A post-ASFA examination of adoption disruption. Adoption Quarterly, 9(4), 19-44. http://doi.org/10.1300/J145vogno4 02

Stiffman, A. R. (1984). A brief measure of children's behavior problems: The Behavior Rating Index for Children. Measurement and Evaluation in Counseling and Development, 17(2), 83-90. https://www.researchgate. net/publication/232565287_A_brief_measure_of_children\%27s_behavior_ problems The Behavior_Rating_Index_for_Children

Strauss, A., \& Corbin, J. (1998). Basics of qualitative research techniques. SAGE Publications.

Suter, E. A. (2008). Discursive negotiation of family identity: A study of U.S. families with adopted children from China. Journal of Family Communication, 8(2), 126-147. https://doi.org/10.1080/15267430701857406

Suter, E. A. (2014). The adopted family. In L. A. Baxter (Ed.), Remaking "family" communicatively (pp. 137-159). Peter Lang.

Suter, E. A., Reyes, K. L., \& Ballard, R. L. (2011a). Adoptive parents' framing of laypersons' conceptions of family. Qualitative Research Reports in Communication, 12(1), 43-50. https://doi.org/10.1080/17459435.2011.601524

Suter, E. A., Reyes, K. L., \& Ballard, R. L. (2011b). Parental management of adoptive identities during challenging encounters: Adoptive parents as 'protectors' and 'educators'. Journal of Social and Personal Relationships, 28(2), 242-261. https://doi.org/10.1177/0265407510384419

Testa, M. F., Snyder, S. M., Wu, Q., Rolock, N., \& Liao, M. (2015). Adoption and guardianship: A moderated mediation analysis of predictors of postpermanency continuity. American Journal of Orthopsychiatry, 85(2), 107-118. http://doi.org/10.1037/ortooooo19

Tracy, S. J. (2013). Qualitative research methods: Collecting evidence, crafting analysis, communicating impact. Wiley-Blackwell. 